\title{
Acid-volatile sulfide and simultaneously extracted metals in surface sediments of the southwestern coastal Laizhou Bay, Bohai Sea: Concentrations, spatial distributions and the indication of heavy metal pollution status
}

\author{
Wen Zhuang a,b, Xuelu Gao ${ }^{\mathrm{a}, *}$ \\ ${ }^{a}$ Key Laboratory of Coastal Environmental Processes and Ecological Remediation, Yantai Institute of Coastal Zone Research, Chinese Academy of Sciences, Yantai, \\ Shandong 264003, China \\ ${ }^{\mathrm{b}}$ University of Chinese Academy of Sciences, Beijing 100049, China
}

\section{A R T I C L E I N F O}

\section{Keywords:}

Acid-volatile sulfide

Simultaneously extracted metal

Heavy metal

Sediment

Laizhou Bay

\begin{abstract}
A B S T R A C T
Surface sediments were collected from the coastal waters of southwestern Laizhou Bay and the rivers it connects with during summer and autumn 2012. The acid-volatile sulfide (AVS) and simultaneously extracted metals (SEM) were measured to assess the sediment quality. The results showed that not all sediments with [SEM]-[AVS] $>0$ were capable of causing toxicity because the organic carbon is also an important metal-binding phase in sediments. Suppose the sediments had not been disturbed and the criteria of US Environmental Protection Agency had been followed, heavy metals in this area had no adverse biological effects in both seasons except for few riverine samples. The major ingredient of SEM was Zn, whereas the contribution of Cd - the most toxic metal studied - to SEM was $<1 \%$. The distributions of AVS and SEM in riverine sediments were more easily affected by anthropogenic activity compared with those in marine sediments.
\end{abstract}

(ㄷ) 2013 Elsevier Ltd. All rights reserved.

\section{Introduction}

Heavy metals in ecosystems have received extensive attention because they are toxic, non-biodegradable in environment and easy to accumulate in organisms. Heavy metal concentrations in aquatic ecosystems have increased considerably due to the inputs of industrial waste, sewage runoff, and agriculture discharges (Prica et al., 2008; Yang et al., 2012). Sediments are the main sink for heavy metals in aquatic ecosystems; however, when environmental conditions such as $\mathrm{pH}$ or sediment redox potential change, sediments may transform to a source of heavy metals (van Den Berg et al., 1999; Wilson and Chang, 2000; Prica et al., 2008).

Acid-volatile sulfide (AVS) is one of the major chemical components that control the speciation and the environmental risks of heavy metals in aquatic sediments. The sulfide ions can combine with most divalent metal ions to form insoluble metal sulfides in anoxic sediments (Ankley, 1996; Huerta-Diaz et al., 1998; USEPA, 2004). If the sulfide ions are in sufficient quantities, the concentrations of heavy metals will be very low in the pore water. Therefore,

* Corresponding author. Address: Key Laboratory of Coastal Environmental Processes and Ecological Remediation, Yantai Institute of Coastal Zone Research, Chinese Academy of Sciences, No. 17 Chunhui Road, Yantai, Shandong 264003, China. Tel.: +86 535 2109132; fax: +86 5352109000.

E-mail address: xlgao@yic.ac.cn (X. Gao). sulfide in sediments has received much attention in the past decades. AVS is operationally defined as reactive solid-phase sulfide fraction that can be extracted with cold hydrochloric acid (1 M or $6 \mathrm{M} \mathrm{HCl}$ ). Metals extracted during the same AVS analyzing process in the sediments are called simultaneously extracted metals (SEM), mainly including $\mathrm{Cd}, \mathrm{Cu}, \mathrm{Ni}, \mathrm{Pb}$ and $\mathrm{Zn}$ (USEPA, 2004). The relationship between the molar concentration of AVS ([AVS], $\mu \mathrm{mol} \mathrm{g}^{-1}$ ) and SEM ([SEM], $\mu \mathrm{mol} \mathrm{g}^{-1}$ ) has been proposed as a possible indicator of metal toxicity in anaerobic sediments (Long et al., 1998; Liu et al., 2010). When the ratio [SEM]/[AVS] $>1$ or [SEM]-[AVS] $>0$, acute toxicity may be generated by heavy metals, whereas the generation of acute toxicity is less possible when [SEM]/[AVS] $<1$ or [SEM]-[AVS] < 0 (Di Toro et al., 1990; Ankley et al., 1996; USEPA, 2004; Di Toro et al., 2005).

However, this approach has its limitations. When the ratio $[\mathrm{SEM}] /[\mathrm{AVS}]>1$, or $[\mathrm{SEM}]-[\mathrm{AVS}]>0$, heavy metal toxicity can be easily overestimated, since other constituents in sediment such as organic matter can also combine with free metal ions, which can reduce their bioavailability and ultimately reduce their toxicity (Burton et al., 2005). It is reported that theoretical expectations have high consistency with experimental results by normalizing the difference between [SEM] and [AVS] to the concentrations of total organic carbon (TOC) in sediments $\left(f_{\text {OC }}\right)$, i.e. ([SEM]-[AVS])/ $f_{\mathrm{OC}}$ (Burton et al., 2005; Di Toro et al., 2005; USEPA, 2005). There 
are also other regulations related to sediment quality, e.g. effects range-low (ERL) and effects range-mean (ERM) concentrations which are empirical approaches based on total metal concentrations (Long et al., 1995). The results cannot provide sufficient information and sometimes it may be misleading to use only total metal concentrations in sediments to assess the toxicity or the bioaccumulation ability of metals, because bioavailability of metals in sediments not only depends on their total concentrations but also on their chemical forms (Sahuquillo et al., 2003; Gao et al., 2008, 2010; Gao and Chen, 2012; Gao and Li, 2012). Furthermore, any metal that is insoluble in the $1 \mathrm{M}$ or $6 \mathrm{M} \mathrm{HCl}$ used in the AVS extraction is unlikely to be bioavailable, and therefore it is non-toxic (Allen et al., 1993; Di Toro et al., 2005). Hence, the AVS approach is suitable for heavy metal toxicity assessment in ecosystems. So far, there are a number of reports on sediment quality assessment by [SEM]/[AVS] or [SEM]-[AVS] method (e.g. Hinkey and Zaidi, 2007; Prica et al., 2008; Liu et al., 2010; Simpson et al., 2012; Gao et al., 2013), but there are only a few studies using ([SEM]-[AVS])/foc (e.g. Burton et al., 2005; Di Toro et al., 2005; De Jonge et al., 2012a; De Jonge et al., 2012b).

Laizhou Bay is one of the three major bays in Bohai Sea, making up $\sim 10 \%$ of its total areas, with a coastline length of $\sim 320 \mathrm{~km}$ and a surface area of $\sim 7000 \mathrm{~km}^{2}$. There are several rivers running into Laizhou Bay from its southwestern coast, most of which are small and seasonal. Laizhou Bay is an important spawning and breeding ground for many marine organisms. Due to abundant seawater resources and underground brine resources, a chemical industrial base called Weifang Binhai Economic Development Zone is located along its southwestern coast. Over 400 chemical enterprises are located nearby and more than 150 kinds of chemical products are manufactured in this area. Now it is one of the biggest manufacturing bases for chlor-alkali products in the world, which produces soda ash, calcium chloride and other chemical products such as sodium silicate, bromine, bromides, and baking soda. Thus, derived from many point sources such as industrial wastewaters and agricultural discharges, non-purified or insufficiently purified wastewaters carrying heavy metals are discharged into the rivers of this area. In 2008, there were 33 tons of heavy metals carried into Laizhou Bay by Xiaoqinghe River (SOA, 2009), and the number soared to 384 tons in 2011 (SOA, 2012). The fishery development and ecological environment of Laizhou Bay have been severely threatened. Therefore it is important to monitor and understand heavy metal bioavailability and toxicity in this area.

This study examined the concentrations of AVS and SEM in the sediments of the southwestern area of Laizhou Bay and the major surrounding rivers with a purpose of trying to elucidate their distribution characteristics and assess the potential toxicity of heavy metals. The southwestern coast of Laizhou Bay was chosen because it is regarded as the most serious threatened area from anthropogenic activities in and surrounding Laizhou Bay (Xia et al., 2009; Liu et al., 2011).

\section{Materials and methods}

\subsection{Sample collection}

The research was carried out in 2012 during two periods: early summer (May-June, hereafter referred to as summer for short), which is before the peak period of the rainy season, and middle autumn (September-October, hereafter referred to as autumn for short), which is after the peak period of the rainy season. The sampling stations were arranged along the major rivers of this area extending from the land to the sea and formed five transects, covering about $15-20 \mathrm{~km}$ from the high tide mark to the land and about $10 \mathrm{~km}$ from the high tide mark to the sea (Fig. 1). The surface sediments of top $5 \mathrm{~cm}$ from the rivers were collected using a plastic spatula, and the surface sediments from the marine region were collected with a stainless steel grab sampler. The samples were placed in polyethylene bottles with no head space or with a nitrogen atmosphere immediately after sampling, and stored in an incubator with ice bags, and then frozen at $-20^{\circ} \mathrm{C}$ within $12 \mathrm{~h}$ until further analysis.

A total of 53 sediment samples were collected in summer and 51 were collected in autumn (Fig. 1) (samples from stations MH3 and YHH2 were collected only in summer), among which 18 marine samples were from the same stations in both sampling periods. The coordinates of corresponding sampling stations during the two periods were not exactly the same, especially in rivers with torrential water flow in autumn. However, all errors were within five meters, so the comparability was considered not to be affected.

\subsection{Analytical methods}

Redox potential (Eh) and $\mathrm{pH}$ of sediments were determined in situ immediately after sampling with redox and $\mathrm{pH}$ electrodes, respectively. The moisture content (MC) was determined by measuring the weight loss after drying at $105{ }^{\circ} \mathrm{C}$ for $24 \mathrm{~h}$. The percentages of water were used to convert the substance contents of the

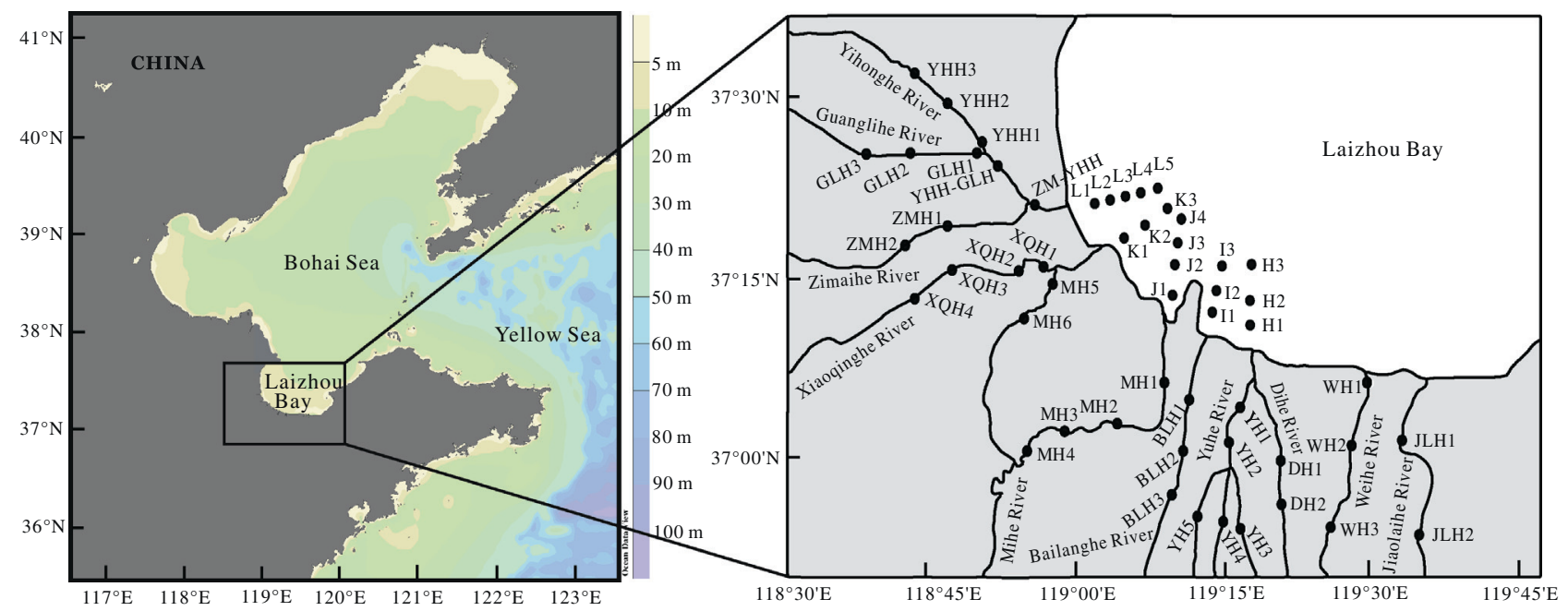

Fig. 1. Location of sampling stations in the coastal zone of SW Laizhou Bay. 
sediments from a wet weight basis to a dry weight basis. The TOC in sediments was obtained by determining the total carbon with an Elementar vario MACRO cube CHNS analyzer after removing the inorganic carbon with $1 \mathrm{M} \mathrm{HCl}$. The particle size distribution was analyzed with a particle size analyzer (Mastersizer 2000, Malvern, Britain) capable of analyzing particle sizes between 0.02 and $2000 \mu \mathrm{m}$. We determined the percentages of the following three groups of grain sizes: $<4 \mu \mathrm{m}$ (clay), $4-63 \mu \mathrm{m}$ (silt), and $>63 \mu \mathrm{m}$ (sand) (Gao and Chen, 2012).

There are two methods most widely applied for AVS and SEM extraction called the purge-and-trap method (Morse et al., 1987) and the diffusion method (van Griethuysen et al., 2002), respectively. Compared with the diffusion method, it is very laborious to use the purge-and-trap method to handle a large number of samples simultaneously: a lot of glassware, gas and space are required (Brouwer and Murphy, 1994). Researchers found that the diffusion method yielded higher AVS concentrations than the purge-and-trap method. They attributed this to the higher efficiency of the diffusion method than the purge-and-trap method and to the prolonged anoxic storage of the samples (Brouwer and Murphy, 1994; Leonard et al., 1996; van Griethuysen et al., 2002). Considering the two points above, a diffusion method modified by van Griethuysen et al. (2002) was used for extracting AVS from $3 \mathrm{~g}$ wet sediment of each sample in this study. $5 \mathrm{~mL} 6 \mathrm{M} \mathrm{HCl}$ were chosen for AVS and SEM extraction, since it is reported that CuS phases of AVS could not be fully extracted with $1 \mathrm{M} \mathrm{HCl}$, and it may possibly result in an underestimation of AVS concentrations in sediments (Simpson et al., 1998; De Jonge et al., 2012a). The volatile hydrogen sulfide $\left(\mathrm{H}_{2} \mathrm{~S}\right)$ was collected in $10 \mathrm{~mL}$ sulfide antioxidant buffer (SAOB) in which the amount of free sulfur ions was measured with an ion specific electrode (van Griethuysen et al., 2002; De Jonge et al., 2012a). The SAOB solution contained $2 \mathrm{M} \mathrm{NaOH}, 0.2 \mathrm{M}$ ascorbic acid and $0.2 \mathrm{M}$ disodium EDTA (van Griethuysen et al., 2002). The remaining sediment extracts were centrifuged for $20 \mathrm{~min}$ at $3000 \mathrm{~g}$, and then the supernatants were collected for SEM ( $\mathrm{Cu}, \mathrm{Pb}, \mathrm{Zn}, \mathrm{Ni}$ and $\mathrm{Cd}$ ) determination.

Apparatus blanks, reagent blanks, calibration curves, and standard recoveries were employed in the analysis. Calibration of the AVS method was done using a standard sodium sulfide to develop a calibration curve (Allen et al., 1993; Hinkey and Zaidi, 2007). Calibration series were accepted when the $R^{2}$ of the relationship between the logarithm of the sulfide concentration and the values of electric potential was above 0.999. Quality control of AVS extraction was assured by calibrating the procedure against known amounts of $\mathrm{Na}_{2} \mathrm{~S} \cdot 9 \mathrm{H}_{2} \mathrm{O}$ (Durán et al., 2012), and recoveries were within $85-94 \%$. Replicates for $20 \%$ of samples were made as a part of the quality assurance and the relative standard deviations were within $10 \%$.

Concentrations of SEM in sediments were measured by an inductively coupled plasma-optical emission spectrometer (ICP-OES; Optima model 7000DV, Perkin Elmer, USA). Standard curves of the metals were made using certified multi-element standard solution. Calibration series were accepted when the $R^{2}$ of the relationship between the concentrations of standard metals and signal values of ICP-OES was above 0.9999. Replicates for $20 \%$ of samples were made as a part of the quality assurance and the relative standard deviations were within $10 \%$ for all the metals studied. Detection limits for ICP-OES measurements (under the optimum wavelength), which were calculated as $3 \times$ standard deviation of 11 measurements of Milli-Q deionized water, were $0.11 \mu \mathrm{mol} \mathrm{L}^{-1}$ for $\mathrm{Cu}$, $0.12 \mu \mathrm{mol} \mathrm{L}^{-1}$ for $\mathrm{Ni}, 0.15 \mu \mathrm{mol} \mathrm{L}^{-1}$ for $\mathrm{Zn}, 0.005 \mu \mathrm{mol} \mathrm{L}^{-1}$ for $\mathrm{Pb}$ and $0.009 \mu \mathrm{mol} \mathrm{L}^{-1}$ for $\mathrm{Cd}$. All results were expressed on the base of the dry weight of the sediment. All reagents were analytical or guaranteed grade and all materials (bottles, tubes, etc.) were cleaned by acid before using.

\subsection{Assessment of heavy metal biotoxicity}

Two methods issued by the United States Environmental Protection Agency (USEPA) were used for assessment of heavy metal biotoxicity: [SEM]-[AVS] (USEPA, 2004) and ([SEM]-[AVS])/foC (USEPA, 2005).

\subsection{Statistical analysis}

All data were tested for normality with the Shapiro-Wilk test before analyzing. The Spearman correlation-coefficient was used to compare the relationship between [AVS], [SEM] and other parameters in pairs. A paired samples t-test $(p<0.05)$ was performed in order to determine whether seasonal changes had significant influence on [AVS] and [SEM], respectively. The above-mentioned analyses were performed through the SPSS statistical package version 19.0 (SPSS Inc.).

\section{Results and discussion}

\subsection{General characteristics of sediments}

In summer, the mineral fraction of particles less than $4 \mu \mathrm{m}$ (clay) varied from nearly $0 \%$ to $22.7 \%$ with an average of $9.5 \%$. The fraction of $4-63 \mu \mathrm{m}$ (silt) particles varied from $4.3 \%$ to $75.2 \%$ with an average of $45.6 \%$. Sand content (>63 $\mu \mathrm{m})$ varied from $11.0 \%$ to $94.6 \%$ with an average of $44.9 \%$. In autumn, the ranges of clay, silt and sand were $2.0-20.1 \%, 8.5-81.0 \%$ and $3.2-90.0 \%$, respectively, with their respective average of $9.0 \%, 47.2 \%$ and $43.8 \%$. Therefore, the sediments in this area were mainly composed of slit and sand (Fig. 2). Marine sediments are usually finer than riverine sediments but it was not the case here. In this research, most riverine sediments were finer than marine sediments, and the components of most marine sediments became finer in the direction from the coast to the sea (Fig. 2). Other researchers also found that the sediments of the southwestern coastal Laizhou Bay were mainly composed of coarse-grained fractions (Qian et al., 2010; Hu et al., 2011). These phenomena were probably the results of the joint effects of the tidal and residual currents and the anti-clockwise circulation of Laizhou Bay which caused the re-suspension of the fine surface sediments near the estuaries and then drove them to the middle of the bay (Jiang et al., 2000; Qian et al., 2010). This was supported by the discovery of a finegrained sediment patch that consisted of silt and clayey silt in the middle of Laizhou Bay, and this sediment patch was composed of suspended sediments derived from rivers especially the Yellow River (Qian et al., 2010).

MC varied from $16.6 \%$ to $47.1 \%$ with an average of $28.5 \%$ in summer; the corresponding data were $18.5-82.7 \%$ and $32.2 \%$ in autumn, respectively (Fig. 3 ). The TOC contents in sediments varied from $0.03 \%$ to $2.1 \%$ with an average of $0.3 \%$ in summer; the corresponding data were $0.2-5.5 \%$ and $0.7 \%$ in autumn, respectively (Fig. 4). The increased TOC contents from summer to autumn revealed the increased bioactivity and bioaccumulation in the aqueous system.

Eh and pH are shown in Figs. 5 and 6, respectively. Eh varied from $-306 \mathrm{mV}$ to $142 \mathrm{mV}$ with an average of $-113 \mathrm{mV}$ in summer, and the corresponding data were $-417 \mathrm{mV}$ to $196 \mathrm{mV}$ and $-101 \mathrm{mV}$ in autumn, respectively. Eh values in each season varied widely among stations and slightly increased from summer to autumn in general. The values of $\mathrm{pH}$ varied from 5.54 to 7.92 with an average of 7.32 in summer, and the corresponding data were 
TOC (\%)

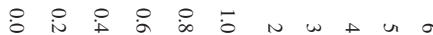

YHH3 $1,1,1,1,-1$

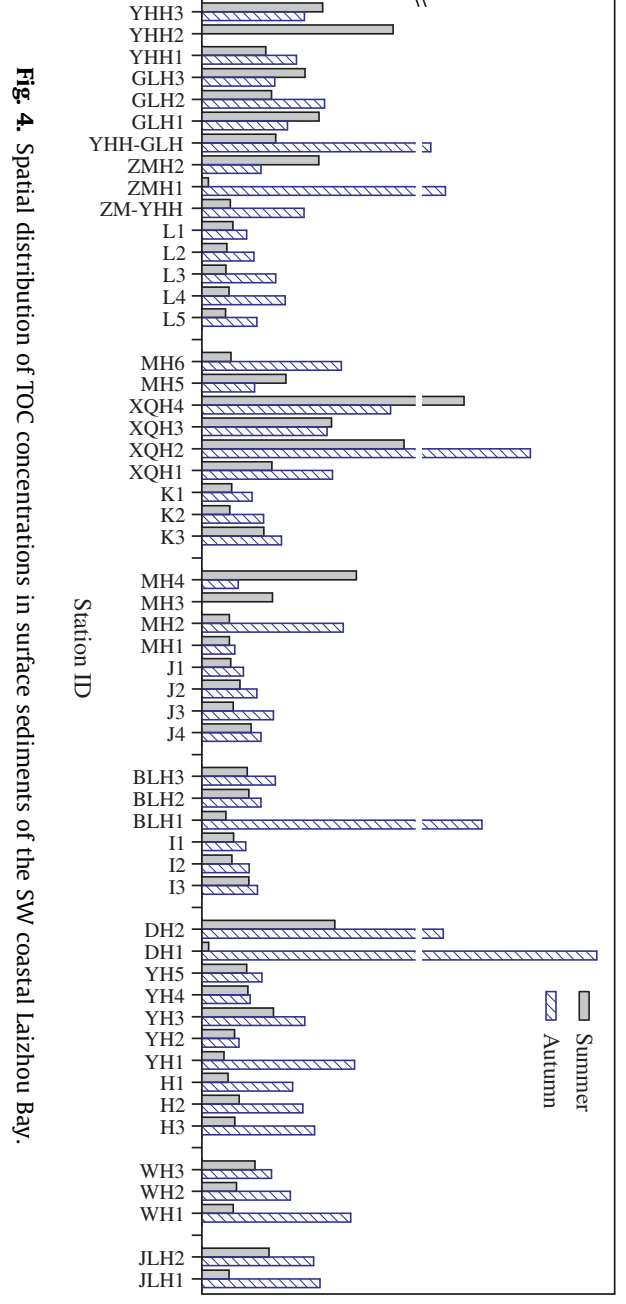

Moisture content (\%)

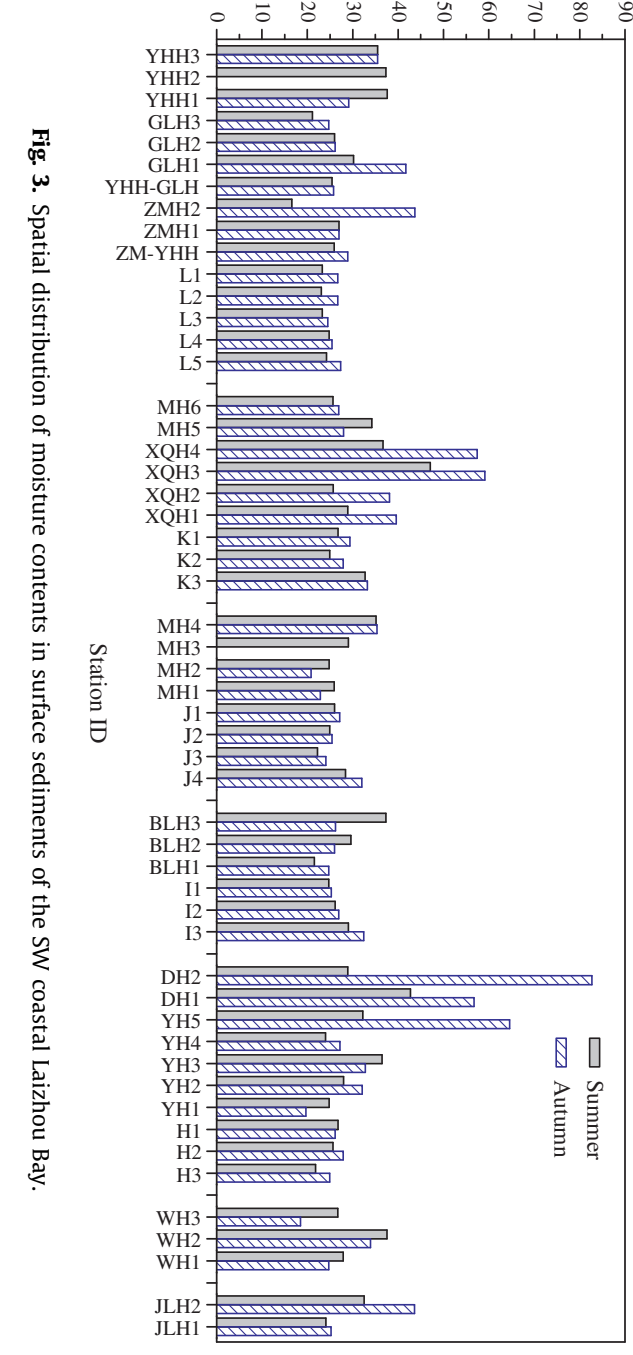

Grain size distribution (\%)

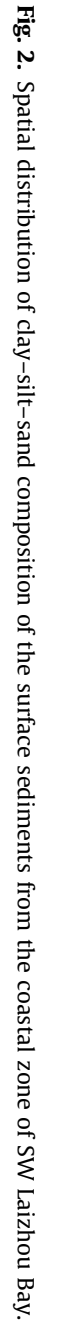

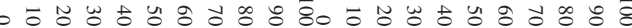

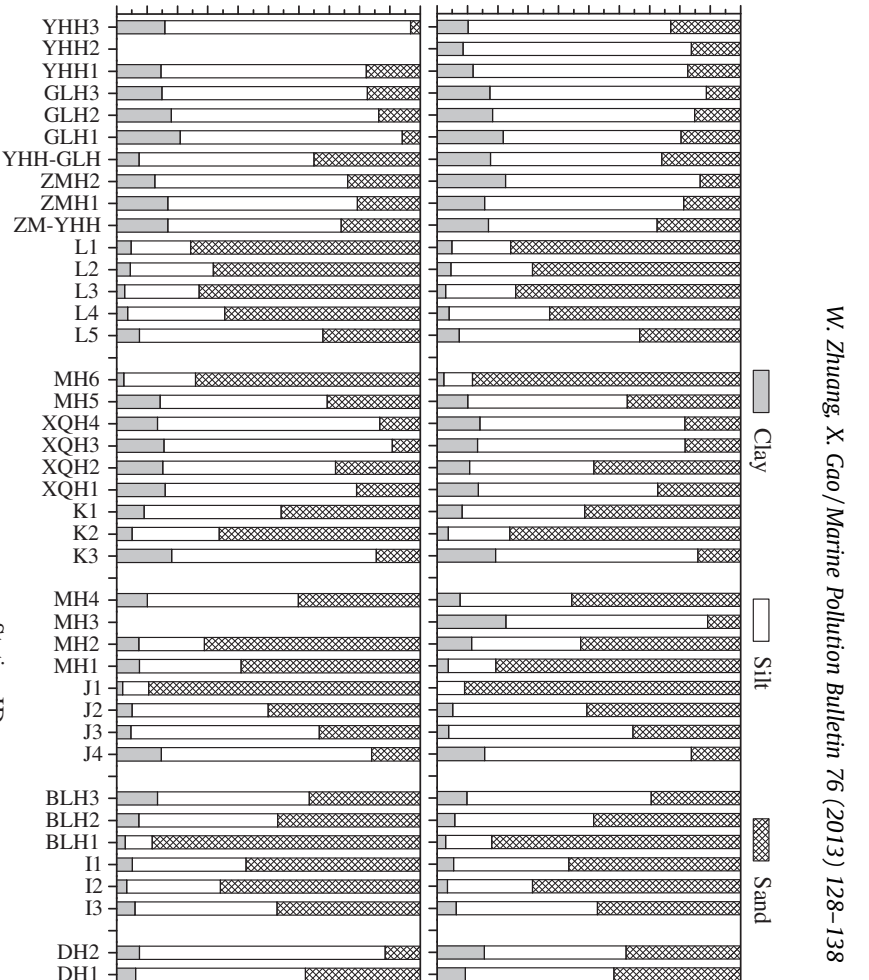




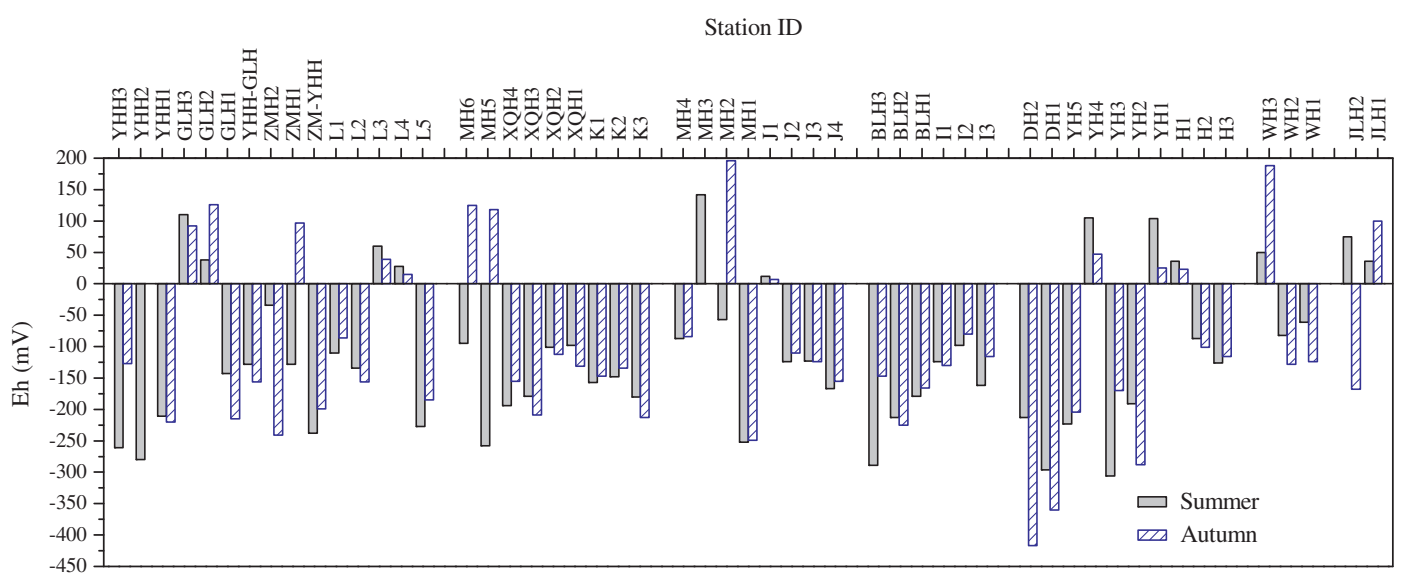

Fig. 5. Spatial distribution of redox potential in surface sediments of the SW coastal Laizhou Bay.

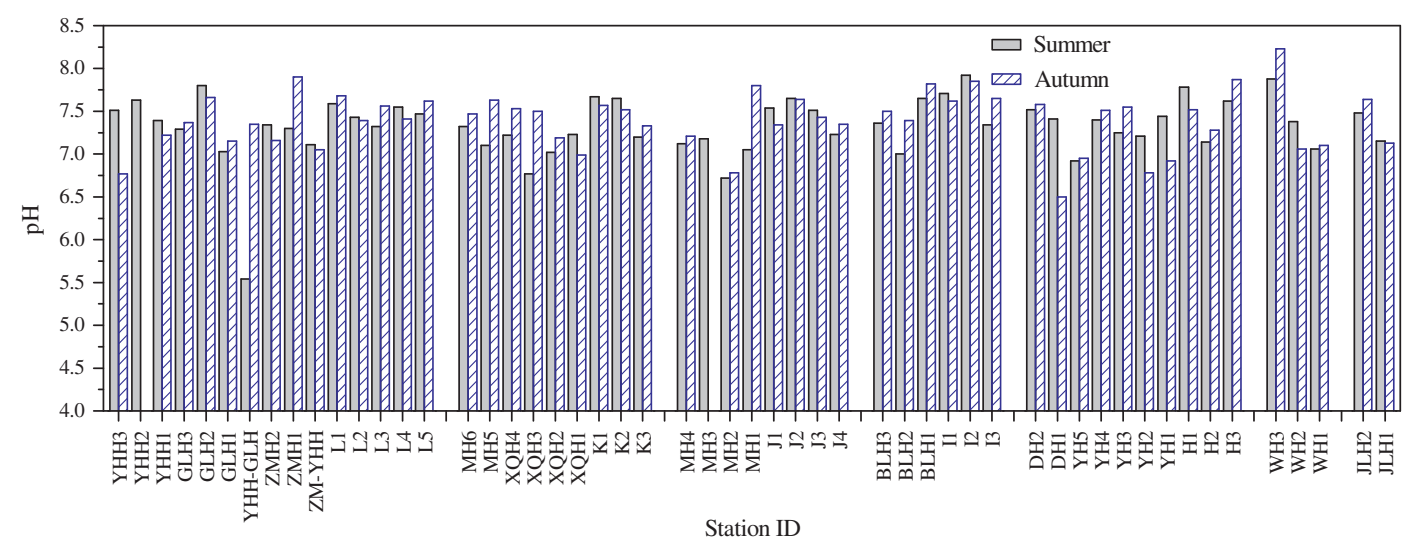

Fig. 6. Spatial distribution of $\mathrm{pH}$ in surface sediments of the SW coastal Laizhou Bay.

6.50-8.23 and 7.39 in autumn, respectively. The range of $\mathrm{pH}$ value in marine sediments was narrower than that in riverine sediments.

\subsection{Distribution characteristics of AVS}

The spatial distribution of AVS is shown in Fig. 7 and related information is summarized in Table 1. Overall, AVS concentrations in riverine sediments were much higher than those in marine sediments; and the differences of AVS concentrations between sediments in rivers were greater than those in the marine area. The mean AVS concentrations in riverine sediments were $26.96 \mu \mathrm{mol} \mathrm{g}^{-1}$ and $21.83 \mu \mathrm{mol} \mathrm{g}^{-1}$ in summer and autumn, respectively; and the relative standard deviations (RSD) were up to 156.8 and 168.8 , respectively. In the marine area, the mean AVS concentrations were $4.98 \mu \mathrm{mol} \mathrm{g}^{-1}$ and $3.61 \mu \mathrm{mol} \mathrm{g}^{-1}$ in summer and autumn, respectively; RSD were 95.0 and 65.7, respectively. The mean AVS concentration in the marine area was close to that of the surface sediments in the offshore area of Laizhou Bay in the previous study carried out in October 2011 (Gao et al., 2013). van Griethuysen et al. (2006) pointed out that sulfate was one of the prerequisites for the formation of AVS and could be a limiting factor in freshwater environments. The previous study in the off-shore area of Laizhou Bay (Gao et al., 2013) showed that the AVS concentration increased in the direction from the river outlet or coast to the sea, which was consistent with the report of van Griethuysen et al. (2006). However, the situation in this study was not the same. Much higher concentrations of AVS were observed in riverine sediments than in marine sediments. The higher AVS concentrations in riverine sediments might be attributed to the relatively higher content of organic matter and finer particles in riverine sediments than in marine sediments, and to the rich terrigenous input and hypoxia status in rivers. Machado et al. (2008) pointed out that sediments with high TOC content and small particle size could result in anoxic conditions due to oxidation of TOC and low oxygen renewal, and then provide an ideal condition for sulfate reducing bacteria (SRB) which could reduce sulfate to sulfide. Spearman correlation analysis showed that [AVS] had significant positive correlations with clay and silt contents, and had significant negative correlation with sand content $(p<0.05)$ in both seasons (Table 2). There was also a significant positive correlation between [AVS] and TOC content $(0.001<p<0.01)$ in summer (Table 2 ), which was consistent with the previous study in the off-shore area of Laizhou Bay (Gao et al., 2013); however, in autumn, there was no significant correlation between [AVS] and TOC content. TOC contents in sediments in summer were much lower than in autumn at almost all the stations; therefore, TOC might be a major limitation for the formation of AVS in summer, but not in autumn. Some other studies also showed that [AVS] and TOC content were not necessarily significantly correlated (Fang et al., 2005; Liu et al., 2007). The forming condition of AVS in riverine and in-shore sediments was much more complex than that in the off-shore area owing to the intensive interaction of a variety of natural and anthropogenic factors.

In Dihe River, Xiaoqinghe River and Yihonghe River, which are the zones with more frequent human activities, higher AVS concentrations were observed (Fig. 7); this might be attributed to the waste discharge from domestic sewage and industrial effluents. The relatively higher AVS concentrations were observed at stations 


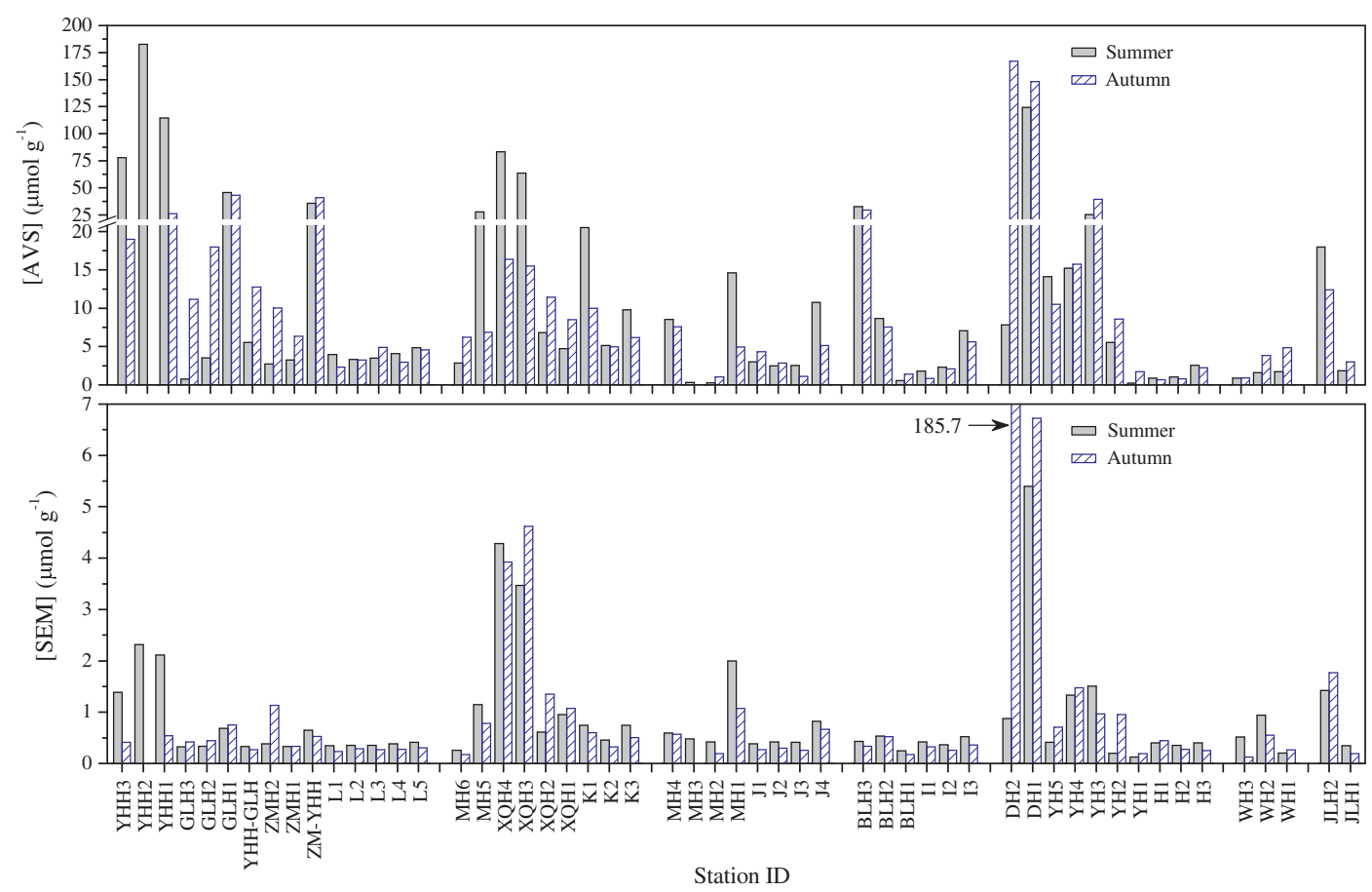

Fig. 7. Spatial distribution of AVS and SEM concentrations in surface sediments of the SW coastal Laizhou Bay.

Table 1

The summary of AVS and SEM contents in surface sediments of the SW coastal Laizhou Bay. The unit $\mu$ mol $\mathrm{g}^{-1}$ is based on dry sediment weight for all parameters.

\begin{tabular}{|c|c|c|c|c|c|c|c|c|c|}
\hline Sampling period & Location & & {$[$ AVS] } & [SEM] & {$[\mathrm{SEM}]_{\mathrm{Cd}}$} & {$[\mathrm{SEM}]_{\mathrm{Ni}}$} & {$[\mathrm{SEM}]_{\mathrm{Cu}}$} & {$[\mathrm{SEM}]_{\mathrm{Pb}}$} & {$[\mathrm{SEM}]_{\mathrm{Zn}}$} \\
\hline \multirow[t]{16}{*}{ Summer } & \multirow[t]{8}{*}{ River } & Min. $\left(\mu \mathrm{mol} \mathrm{g}{ }^{-1}\right)$ & 0.25 & 0.13 & $<0.0001$ & 0.030 & 0.002 & 0.010 & 0.064 \\
\hline & & $\operatorname{Max} .\left(\mu \mathrm{mol} \mathrm{g}{ }^{-1}\right)$ & 182.73 & 5.40 & 0.0027 & 0.196 & 1.206 & 0.149 & 4.94 \\
\hline & & Mean $\left(\mu \mathrm{mol} \mathrm{g}^{-1}\right)$ & 26.96 & 1.07 & 0.0007 & 0.106 & 0.218 & 0.041 & 0.702 \\
\hline & & SD & 42.27 & 1.20 & 0.0006 & 0.050 & 0.256 & 0.032 & 1.04 \\
\hline & & RSD (\%) & 156.8 & 112.4 & 91.3 & 46.7 & 117.5 & 79.0 & 148.1 \\
\hline & & Min. (\%) & & & 0.01 & 2.33 & 1.21 & 0.86 & 27.04 \\
\hline & & Max. (\%) & & & 0.22 & 33.03 & 56.84 & 13.46 & 91.48 \\
\hline & & Mean (\%) & & & 0.08 & 17.13 & 23.16 & 5.69 & 53.94 \\
\hline & \multirow[t]{8}{*}{ Sea } & Min. $\left(\mu \mathrm{mol} \mathrm{g}{ }^{-1}\right)$ & 0.86 & 0.35 & 0.0002 & 0.103 & 0.051 & 0.008 & 0.147 \\
\hline & & $\operatorname{Max} .\left(\mu \mathrm{mol} \mathrm{g}{ }^{-1}\right)$ & 20.51 & 0.82 & 0.0014 & 0.190 & 0.243 & 0.066 & 0.396 \\
\hline & & Mean $\left(\mu \mathrm{mol} \mathrm{g}{ }^{-1}\right)$ & 4.98 & 0.46 & 0.0008 & 0.122 & 0.104 & 0.029 & 0.206 \\
\hline & & SD & 4.73 & 0.15 & 0.0004 & 0.025 & 0.057 & 0.015 & 0.066 \\
\hline & & RSD (\%) & 95.0 & 32.3 & 49.0 & 20.5 & 54.9 & 51.9 & 32.0 \\
\hline & & Min. (\%) & & & 0.05 & 19.12 & 13.22 & 2.08 & 37.03 \\
\hline & & Max. (\%) & & & 0.33 & 31.32 & 31.30 & 12.26 & 57.64 \\
\hline & & Mean (\%) & & & 0.18 & 27.28 & 21.46 & 6.12 & 44.96 \\
\hline \multirow[t]{16}{*}{ Autumn } & \multirow[t]{8}{*}{ River } & Min. $\left(\mu \mathrm{mol} \mathrm{g}{ }^{-1}\right)$ & 0.93 & 0.12 & $<0.0001$ & 0.035 & 0.014 & 0.008 & 0.050 \\
\hline & & $\operatorname{Max} .\left(\mu \mathrm{mol} \mathrm{g}{ }^{-1}\right)$ & 167.05 & 185.68 & 0.0069 & 0.591 & 0.778 & 0.125 & 185.0 \\
\hline & & Mean $\left(\mu \mathrm{mol} \mathrm{g}{ }^{-1}\right)$ & 21.83 & 6.64 & 0.0009 & 0.099 & 0.158 & 0.033 & 6.35 \\
\hline & & SD & 36.85 & 32.17 & 0.0016 & 0.096 & 0.172 & 0.024 & 32.1 \\
\hline & & RSD (\%) & 168.8 & 484.3 & 167.9 & 96.6 & 108.8 & 71.8 & 505.4 \\
\hline & & Min. (\%) & & & 0.003 & 0.32 & 0.01 & 0.04 & 33.15 \\
\hline & & Max. (\%) & & & 0.64 & 32.67 & 49.10 & 9.35 & 99.64 \\
\hline & & Mean (\%) & & & 0.08 & 15.49 & 21.28 & 5.01 & 58.14 \\
\hline & \multirow[t]{8}{*}{ Sea } & Min. $\left(\mu \mathrm{mol} \mathrm{g}{ }^{-1}\right)$ & 0.70 & 0.23 & 0.0001 & 0.047 & 0.029 & 0.005 & 0.077 \\
\hline & & $\operatorname{Max} .\left(\mu \mathrm{mol} \mathrm{g}{ }^{-1}\right)$ & 10.00 & 0.67 & 0.0011 & 0.174 & 0.186 & 0.053 & 0.342 \\
\hline & & Mean $\left(\mu \mathrm{mol} \mathrm{g}^{-1}\right)$ & 3.61 & 0.35 & 0.0004 & 0.087 & 0.072 & 0.023 & 0.163 \\
\hline & & SD & 2.37 & 0.13 & 0.0003 & 0.029 & 0.040 & 0.013 & 0.076 \\
\hline & & RSD (\%) & 65.7 & 36.5 & 74.5 & 33.8 & 56.0 & 58.5 & 46.8 \\
\hline & & Min. (\%) & & & 0.04 & 14.02 & 6.58 & 1.95 & 30.01 \\
\hline & & Max. (\%) & & & 0.33 & 41.39 & 30.74 & 14.24 & 77.28 \\
\hline & & Mean (\%) & & & 0.13 & 26.12 & 20.48 & 6.63 & 46.64 \\
\hline
\end{tabular}

$[\mathrm{SEM}]=[\mathrm{SEM}]_{\mathrm{Cd}}+[\mathrm{SEM}]_{\mathrm{Ni}}+[\mathrm{SEM}]_{\mathrm{Cu}}+[\mathrm{SEM}]_{\mathrm{Pb}}+[\mathrm{SEM}]_{\mathrm{Zn}}$.

YHH1 (summer), YHH2 (summer), DH1 (summer and autumn) and DH2 (autumn) (Fig. 7), and the mean Eh values at these stations were lower than $-200 \mathrm{mV}$, especially in DH2 whose Eh value was even lower than $-400 \mathrm{mV}$ (autumn) (Fig. 5). Sediments from these stations were in severe hypoxia status. The significant negative correlation between [AVS] and Eh $(p<0.001)$ in both summer and autumn proved the relationship between AVS concentration and the redox status in sediments of the studied area (Table 2). 
Table 2

Spearman correlation matrix for the components and parameters of the surface sediments from the SW coastal Laizhou Bay.

\begin{tabular}{|c|c|c|c|c|c|c|c|c|c|c|c|c|c|c|c|}
\hline $\begin{array}{l}\text { Sampling } \\
\text { period }\end{array}$ & & [AVS] & [SEM] & {$[\mathrm{SEM}]_{\mathrm{Cd}}$} & {$[\mathrm{SEM}]_{\mathrm{Cu}}$} & {$[\mathrm{SEM}]_{\mathrm{Ni}}$} & {$[\mathrm{SEM}]_{\mathrm{Pb}}$} & {$[\mathrm{SEM}]_{\mathrm{Zn}}$} & \%TOC & $\% \mathrm{MC}$ & \%Clay & \%Silt & \%Sand & $\mathrm{pH}$ & Eh \\
\hline Summer & $\begin{array}{l}{[\mathrm{AVS}]} \\
{[\mathrm{SEM}]} \\
{[\mathrm{SEM}]_{\mathrm{Cd}}} \\
{[\mathrm{SEM}]_{\mathrm{Cu}}} \\
{[\mathrm{SEM}]_{\mathrm{Ni}}} \\
{[\mathrm{SEM}]_{\mathrm{Pb}}} \\
{[\mathrm{SEM}]_{\mathrm{Zn}}}\end{array}$ & 1.000 & $\begin{array}{l}0.717^{a} \\
1.000\end{array}$ & $\begin{array}{l}0.254^{\mathrm{a}} \\
0.558^{\mathrm{a}} \\
1.000\end{array}$ & $\begin{array}{l}0.548^{\mathrm{a}} \\
0.773^{\mathrm{a}} \\
0.492^{\mathrm{a}} \\
1.000\end{array}$ & $\begin{array}{l}0.339^{\mathrm{c}} \\
0.603^{\mathrm{a}} \\
0.468^{\mathrm{a}} \\
0.688^{\mathrm{a}} \\
1.000\end{array}$ & $\begin{array}{l}0.583^{\mathrm{a}} \\
0.669^{\mathrm{a}} \\
0.322^{\mathrm{c}} \\
0.755^{\mathrm{a}} \\
0.632^{\mathrm{a}} \\
1.000\end{array}$ & $\begin{array}{l}0.686^{\mathrm{a}} \\
0.930^{\mathrm{a}} \\
0.587^{\mathrm{a}} \\
0.610^{\mathrm{a}} \\
0.509^{\mathrm{a}} \\
0.584^{\mathrm{a}} \\
1.000\end{array}$ & $\begin{array}{l}0.404^{\mathrm{b}} \\
0.469^{\mathrm{a}} \\
0.293^{\mathrm{c}} \\
0.550^{\mathrm{a}} \\
0.246 \\
0.545^{\mathrm{a}} \\
0.424^{\mathrm{b}}\end{array}$ & $\begin{array}{l}0.626^{\mathrm{a}} \\
0.660^{\mathrm{a}} \\
0.301^{\mathrm{c}} \\
0.506^{\mathrm{a}} \\
0.418^{\mathrm{b}} \\
0.470^{\mathrm{a}} \\
0.621^{\mathrm{a}}\end{array}$ & $\begin{array}{l}0.319^{c} \\
0.281^{c} \\
0.010 \\
0.462^{\mathrm{a}} \\
0.193 \\
0.577^{\mathrm{a}} \\
0.186\end{array}$ & $\begin{array}{l}0.453^{\mathrm{a}} \\
0.394^{\mathrm{b}} \\
0.267 \\
0.587^{\mathrm{a}} \\
0.259 \\
0.650^{\mathrm{a}} \\
0.254\end{array}$ & $\begin{array}{l}-0.392^{\mathrm{b}} \\
-0.336^{\mathrm{c}} \\
-0.197 \\
-0.554^{\mathrm{a}} \\
-0.227 \\
-0.640^{\mathrm{a}} \\
-0.200\end{array}$ & $\begin{array}{l}-0.225 \\
-0.118 \\
0.129 \\
-0.201 \\
0.007 \\
-0.169 \\
-0.086\end{array}$ & $\begin{array}{l}-0.698^{\mathrm{a}} \\
-0.470^{\mathrm{a}} \\
-0.110 \\
-0.413^{\mathrm{b}} \\
-0.236 \\
-0.269 \\
-0.408^{\mathrm{b}}\end{array}$ \\
\hline Autumn & $\begin{array}{l}{[\mathrm{AVS}]} \\
{[\mathrm{SEM}]} \\
{[\mathrm{SEM}]_{\mathrm{Cd}}} \\
{[\mathrm{SEM}]_{\mathrm{Cu}}} \\
{[\mathrm{SEM}]_{\mathrm{Ni}}} \\
{[\mathrm{SEM}]_{\mathrm{Pb}}} \\
{[\mathrm{SEM}]_{\mathrm{Zn}}}\end{array}$ & 1.000 & $\begin{array}{l}0.696^{a} \\
1.000\end{array}$ & $\begin{array}{l}0.314^{\mathrm{c}} \\
0.655^{\mathrm{a}} \\
1.000\end{array}$ & $\begin{array}{l}0.547^{\mathrm{a}} \\
0.658^{\mathrm{a}} \\
0.555^{\mathrm{a}} \\
1.000\end{array}$ & $\begin{array}{l}0.409^{\mathrm{b}} \\
0.507^{\mathrm{a}} \\
0.463^{\mathrm{a}} \\
0.684^{\mathrm{a}} \\
1.000\end{array}$ & $\begin{array}{l}0.620^{\mathrm{a}} \\
0.647^{\mathrm{a}} \\
0.445^{\mathrm{a}} \\
0.754^{\mathrm{a}} \\
0.749^{\mathrm{a}} \\
1.000\end{array}$ & $\begin{array}{l}0.609^{\mathrm{a}} \\
0.954^{\mathrm{a}} \\
0.619^{\mathrm{a}} \\
0.526^{\mathrm{a}} \\
0.375^{\mathrm{b}} \\
0.520^{\mathrm{a}} \\
1.000\end{array}$ & $\begin{array}{l}0.199 \\
-0.055 \\
-0.085 \\
-0.037 \\
-0.088 \\
0.153 \\
-0.031\end{array}$ & $\begin{array}{l}0.628^{\mathrm{a}} \\
0.754^{\mathrm{a}} \\
0.570^{\mathrm{a}} \\
0.525^{\mathrm{a}} \\
0.580^{\mathrm{a}} \\
0.630^{\mathrm{a}} \\
0.736^{\mathrm{a}}\end{array}$ & $\begin{array}{l}0.622^{\mathrm{a}} \\
0.577^{\mathrm{a}} \\
0.288^{\mathrm{c}} \\
0.797^{\mathrm{a}} \\
0.598^{\mathrm{a}} \\
0.745^{\mathrm{a}} \\
0.464^{\mathrm{a}}\end{array}$ & $\begin{array}{l}0.622^{\mathrm{a}} \\
0.578^{\mathrm{a}} \\
0.493^{\mathrm{a}} \\
0.787^{\mathrm{a}} \\
0.686^{\mathrm{a}} \\
0.811^{\mathrm{a}} \\
0.458^{\mathrm{a}}\end{array}$ & $\begin{array}{l}-0.639^{\mathrm{a}} \\
-0.600^{\mathrm{a}} \\
-0.463^{\mathrm{a}} \\
-0.820^{\mathrm{a}} \\
-0.682^{\mathrm{a}} \\
-0.824^{\mathrm{a}} \\
-0.481^{\mathrm{a}}\end{array}$ & $\begin{array}{l}-0.277 \\
-0.204 \\
-0.126 \\
-0.117 \\
-0.193 \\
-0.234 \\
-0.240\end{array}$ & $\begin{array}{l}-0.439^{\mathrm{a}} \\
-0.536^{\mathrm{a}} \\
-0.583^{\mathrm{a}} \\
-0.415^{\mathrm{b}} \\
-0.351^{\mathrm{c}} \\
-0.328^{\mathrm{c}} \\
-0.495^{\mathrm{a}}\end{array}$ \\
\hline
\end{tabular}

\footnotetext{
a $p<0.001$.

b $0.001<p<0.01$.

c $0.01<p<0.05$.
}

AVS concentrations in sediments of most riverine stations increased from summer to autumn, which might be the results of the sharp metabolism of SRB with abundant nutritional materials in summer. The increased TOC concentrations from summer to autumn at most riverine stations can be good evidence for this phenomenon (Fig. 4). However, AVS concentrations in sediments of about one third of the stations in rivers decreased from summer to autumn (Fig. 7). The concentration of AVS in the sediment is determined by both the rate at which AVS is produced and the rate at which it is lost by oxidation or diffusion. It has been reported that sediments colonized by plants displayed more strongly oxidizing conditions than unvegetated sediments, and living plants can significantly decrease AVS concentrations in sediments (Jacob and Otte, 2004; Almeida et al., 2005). In middle autumn, plants were more flourishing than in early summer; this might be one of the reasons for the [AVS] decrease in sediments of some riverine stations. Moreover, AVS concentrations among stations were very different even during the same sampling period. Therefore, it is impossible to find out all the factors causing these phenomena since the dissolved sulfate concentration, organic matter availability, SRB community size, temperature, and even plants are all important variables for the fate and dynamics of AVS (Machado et al., 2008; Yang et al., 2012).

In the marine area, only in sediments of stations $\mathrm{J} 1, \mathrm{~J} 2$ and L3 AVS concentrations were higher in autumn than in summer, and AVS concentrations at all the other 15 stations decreased from summer to autumn (Fig. 7). It has been reported that $\mathrm{O}_{2}$ saturation and SRB activities played important roles in AVS formation and degradation (van Griethuysen et al., 2006). Wijsman et al. (2001) pointed out that AVS could exist near the sediment-water interface during anoxia, while it was easily oxidized under oxic conditions. In autumn the wind was stronger on the sea than in summer, and waves were much greater, which might cause the increase of the dissolved oxygen content, and then oxidize AVS. Raised Eh was observed in some marine sediments from autumn to summer (Fig. 5). Most SRB are mesophilic bacteria or thermophilic bacteria with optimum temperature ranges of $25-40{ }^{\circ} \mathrm{C}$ (Morita, 1975), and are sensitive to temperature changes (Castro et al., 2000). In summer, the mean temperature in surface seawater was above $25^{\circ} \mathrm{C}$, however, in autumn the mean temperature was only $18^{\circ} \mathrm{C}$. The decreased temperature might result in the decreased activities of SRB. Nevertheless, no information is available for this specific case study up to now. In order to ascertain whether or not SRB plays an important role in the AVS concentration changes in this area, further research is needed.
Table 3

Statistical analysis of the dependence of [AVS] and [SEM] between the sampling periods.

\begin{tabular}{llll}
\hline Location & Content & $p$-Value & $\begin{array}{l}\text { Significant difference } \\
\text { at level } 0.05\end{array}$ \\
\hline River & {$[\mathrm{AVS}]$} & 0.853 & No \\
& {$[\mathrm{SEM}]$} & 0.918 & No \\
& {$[\mathrm{SEM}]_{\mathrm{Cd}}$} & 0.348 & No \\
& {$[\mathrm{SEM}]_{\mathrm{Ni}}$} & 0.784 & No \\
& {$[\mathrm{SEM}]_{\mathrm{Cu}}$} & 0.293 & No \\
& {$[\mathrm{SEM}]_{\mathrm{Pb}}$} & 0.353 & No \\
& {$[\mathrm{SEM}]_{\mathrm{Zn}}$} & 0.527 & No \\
Sea & {$[\mathrm{AVS}]$} & 0.055 & No \\
& {$[\mathrm{SEM}]$} & $8.26 \times 10^{-8}$ & Yes \\
& {$[\mathrm{SEM}]_{\mathrm{Cd}}$} & $1.12 \times 10^{-5}$ & Yes \\
& {$[\mathrm{SEM}]_{\mathrm{Ni}}$} & $2.06 \times 10^{-7}$ & Yes \\
& {$[\mathrm{SEM}]_{\mathrm{Cu}}$} & $5.29 \times 10^{-5}$ & Yes \\
& {$[\mathrm{SEM}]_{\mathrm{Pb}}$} & $4.45 \times 10^{-6}$ & Yes \\
& {$[\mathrm{SEM}]_{\mathrm{Zn}}$} & 0.002 & Yes \\
\hline
\end{tabular}

The paired samples $t$-test showed that no significant correlation existed between AVS concentrations of the two sampling phases in both riverine and marine sediments ( $p>0.05$; Table 3 ). Thus, AVS concentrations did not simply depend on seasonal changes, which further indicated that formation and persistence of AVS in the sediments of this area were complex.

\subsection{Distribution characteristics of SEM}

The spatial distribution of SEM is shown in Fig. 7 and related information is summarized in Table 1. Generally, the mean [SEM] was found to decrease from summer to autumn in marine sediments, but seemed to increase in riverine sediments. If the unusually high $[\mathrm{SEM}]_{\mathrm{Zn}}\left(185.0 \mu \mathrm{mol} \mathrm{g}^{-1}\right)$ in $\mathrm{DH} 2$ in autumn was neglected (Figs. 7 and 8), the mean [SEM] in riverine sediments in autumn was only $1.06 \mu \mathrm{mol} \mathrm{g}^{-1}$, which was almost the same as that in summer $\left(1.07 \mu \mathrm{mol} \mathrm{g}^{-1}\right)$ (Table 1$)$. Mean [SEM] was higher in riverine sediments than in marine sediments, and this distribution characteristic was in accordance with [AVS], indicating the impact of human activities and surface runoff on the heavy metal contents. Variation ranges of SEM contents among stations and between seasons were much narrower than those of AVS, which showed that SEM was more evenly distributed compared with AVS. Relatively higher [SEM] was observed in Dihe River, Xiaoqinghe River and Yihonghe River, which was also in accordance with 


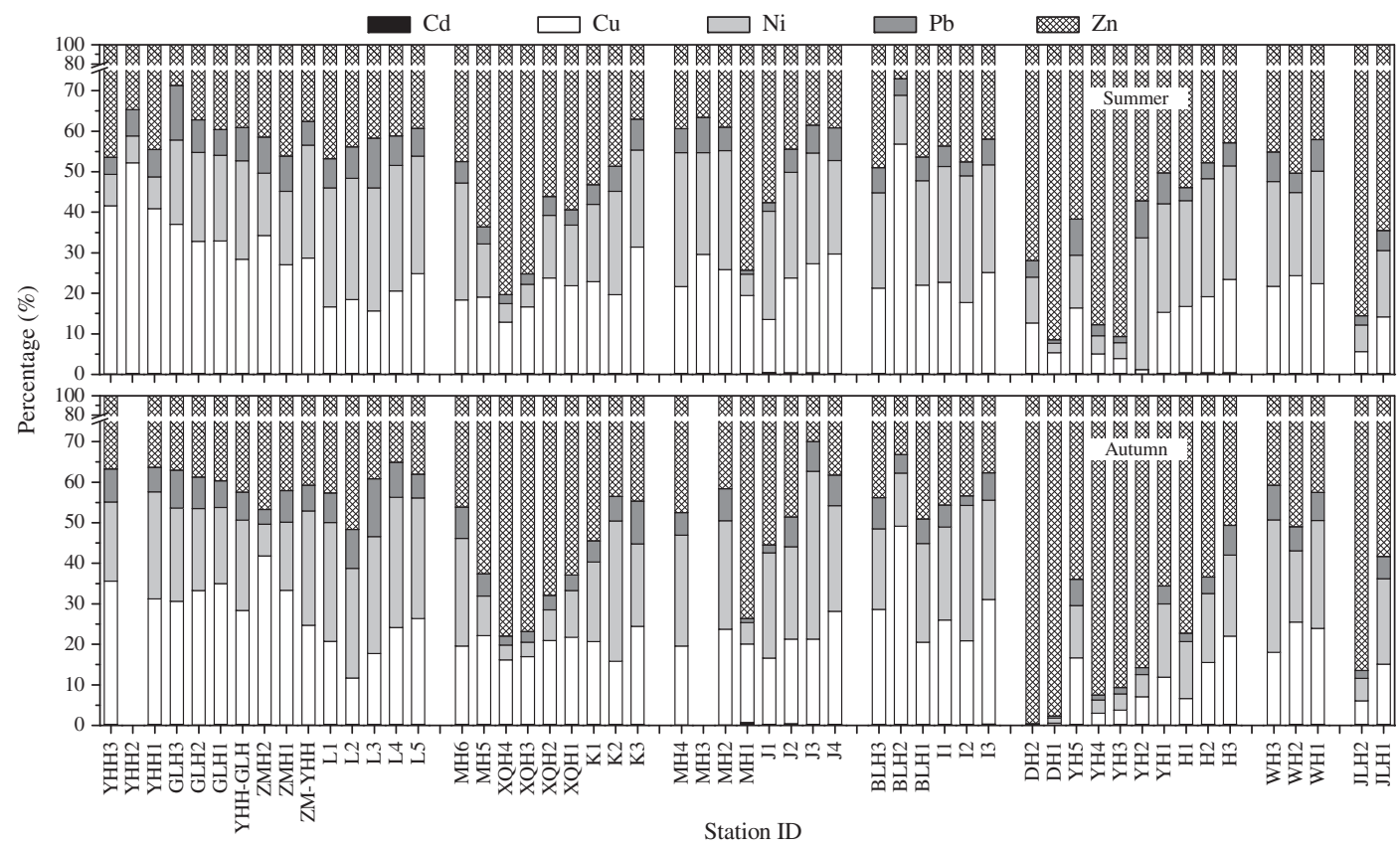

Fig. 8. Spatial distribution of relative concentrations of SEM components in surface sediments of the SW coastal Laizhou Bay.

the distribution characteristics of [AVS] (Fig. 7). The significant positive correlations between [SEM] and [AVS] $(p<0.001)$ and between components of SEM and [AVS] $(p<0.05)$ in both summer and autumn confirmed that AVS was an important carrier for SEM (Table 2).

Extremely high $[\mathrm{SEM}]\left(185.68 \mu \mathrm{mol} \mathrm{g}^{-1}\right)$ and $[\mathrm{SEM}]_{\mathrm{Zn}}(185.0)$ were found in DH2 in autumn, and the corresponding values were only $0.87 \mu \mathrm{mol} \mathrm{g}^{-1}$ and $0.63 \mu \mathrm{mol} \mathrm{g}^{-1}$ in summer, respectively (Figs. 7 and 8). It was impossible that such a big change was merely caused by natural factors, and it could be probably attributed to the wastewater discharge from factories. Several chemical plants are located near DH2, and an outfall was found in the upstream about dozens of meters away from $\mathrm{DH} 2$, but it could not be determined to which chemical plant it belongs. Studies showed that anthropogenic metals were more loosely bound to sediments and might be released back to the aqueous phase with the change of physical and chemical characteristics (Eh, pH, salinity and TOC) (Soares et al., 1999). Therefore, pollution risk of anthropogenic heavy metals is much higher.

Compared with other metals, $\mathrm{Zn}$ was the major part of SEM in all samples and accounted for approximately $27.0-99.6 \%$ of the total amount of SEM, whereas the contribution of $\mathrm{Cd}$ - the most toxic metal studied - to SEM was less than 1\% (Fig. 8; Table 1). The average concentrations of SEM components were in the following order: $[\mathrm{SEM}]_{\mathrm{Cd}} \ll[\mathrm{SEM}]_{\mathrm{Pb}}<[\mathrm{SEM}]_{\mathrm{Ni}}<[\mathrm{SEM}]_{\mathrm{Cu}}<[\mathrm{SEM}]_{\mathrm{Zn}}$ (Fig. 8), which was consistent with the order in the previous study in the off-shore area of Laizhou Bay (Gao et al., 2013). There were significant positive correlations between [SEM] and TOC and between components of SEM (except $[\mathrm{SEM}]_{\mathrm{Ni}}$ ) and TOC in summer $(p<0.001)$, but these were not true in autumn (Table 2 ). The results indicated that TOC might be one of the major carriers of SEM as important as AVS in summer, but SEM might be mainly combined with AVS or other substances in autumn. However, the pervious study in October 2011 showed that there was a significant positive correlation between [SEM] and TOC in off-shore sediment in Laizhou Bay (Gao et al., 2013). These facts indicated the different combined status of SEM between off-shore and in-shore sediments in Laizhou Bay. Significant positive correlations in both summer and autumn were observed between $[\mathrm{SEM}]_{\mathrm{Cd}},[\mathrm{SEM}]_{\mathrm{Pb}},[\mathrm{SEM}]_{\mathrm{Ni}},[\mathrm{SEM}]_{\mathrm{Cu}}$, and $[\mathrm{SEM}]_{\mathrm{Zn}}$ in pairs, which indicated that these metals were associated with each other and might have common anthropogenic and natural sources in the sediments (Table 2). All simultaneously extracted metals showed significant positive correlations with MC and finegrained fractions (clay + silt) and significant negative correlations with coarse fractions (sand) in autumn as AVS did, implying the similar formative and existing conditions of AVS and SEM in this period (Table 2). However, the fine-grained fraction showed nonsignificant positive relationships with $\mathrm{Cd}$, Ni and $\mathrm{Zn}$ in summer (Table 2), which was in consistence with the studies carried out by Ip et al. (2007) in Pearl River Estuary and its surrounding coastal area, implying that the concentration of heavy metals in sediments cannot be simply interpreted by changes in grain size.

The paired samples $t$-test showed that seasonal changes had strong effects on the distribution of SEM in marine sediments (the corresponding $p$-values were between $8.264 \times 10^{-8}$ and 0.002 ) but not in riverine sediments (Table 3 ). The $t$-test results reflected that other factors (variability in terrestrial inputs, hydrodynamic process and deposition conditions, etc.) besides seasonal changes might influence the distribution characteristics of SEM in rivers. In short, formation and persistence of SEM in riverine sediments were also more complex than in marine sediments as AVS did.

\subsection{Evaluation of sediment toxicity}

SEM could react with AVS to form insoluble metal sulfides which are non-bioavailable for benthic organisms. If SEM is present at lower concentrations than AVS, there is a low probability of toxicity; if the concentration of SEM is greater than that of AVS, the excess fraction of the divalent metals potentially exist as free metal ions and could cause toxicity (McGrath et al., 2002; Hinkey and Zaidi, 2007). Based on this theory, each sample falls into one of the three tiers: Tier 1, associated adverse effects on aquatic life are probable ([SEM]-[AVS] $>5$, unit: $\mu \mathrm{mol} \mathrm{g}^{-1}$ ); Tier 2, associated adverse effects on aquatic life are possible $(0<[S E M]-[A V S]<5)$; Tier 3 , there is no indication of associated adverse effects ([SEM]-[AVS] < 0) (Table 4) (USEPA, 2004). According to the AVSSEM criterion, the surface sediment at site $\mathrm{DH} 2$ belonged to Tier 1 in autumn; the surface sediments at sites $\mathrm{MH} 2$ and $\mathrm{MH} 3$ belonged to Tier 2 in summer; the sediments of other sites might 
Table 4

Sediment quality guidelines and the classification results.

\begin{tabular}{|c|c|c|c|c|c|c|c|}
\hline \multirow[t]{3}{*}{ Sediment quality guideline } & \multirow[t]{3}{*}{ Classification } & \multirow[t]{3}{*}{ Criterion used to determine classification } & \multirow[t]{3}{*}{ Reference } & \multicolumn{4}{|c|}{ Number of sampling stations } \\
\hline & & & & \multicolumn{2}{|c|}{ Summer } & \multicolumn{2}{|c|}{ Autumn } \\
\hline & & & & River & Sea & River & Sea \\
\hline \multirow[t]{3}{*}{ [SEM]-[AVS] } & Tier 1 & {$[$ SEM] $]-[$ AVS $]>5$} & \multirow[t]{3}{*}{ USEPA (2004) } & 0 & 0 & 1 & 0 \\
\hline & Tier 2 & {$[\mathrm{SEM}]-[\mathrm{AVS}]=0$ to 5} & & 2 & 0 & 0 & 0 \\
\hline & Tier 3 & {$[$ SEM $]-[$ AVS $]<0$} & & 33 & 18 & 32 & 18 \\
\hline \multirow[t]{3}{*}{$([\mathrm{SEM}]-[\mathrm{AVS}]) / f_{\mathrm{OC}}$} & Tier 1 & $([\mathrm{SEM}]-[\mathrm{AVS}]) / f_{\mathrm{OC}}>3000$ & \multirow[t]{3}{*}{ USEPA (2005) } & 0 & 0 & 0 & 0 \\
\hline & Tier 2 & $([\mathrm{SEM}]-[\mathrm{AVS}]) / f_{\mathrm{OC}}=130-3000$ & & 0 & 0 & 1 & 0 \\
\hline & Tier 3 & $([\mathrm{SEM}]-[\mathrm{AVS}]) / f_{\mathrm{OC}}<130$ & & 35 & 18 & 32 & 18 \\
\hline
\end{tabular}

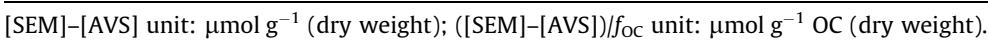

Table 5

Information about the sampling stations that had potential ecological risk.

\begin{tabular}{lllll}
\hline Station & $\begin{array}{l}\text { Sampling } \\
\text { period }\end{array}$ & $\begin{array}{l}\text { Sediment quality } \\
\text { guideline }\end{array}$ & Value & Classification \\
\hline MH2 & Summer & [SEM]-[AVS] & 0.12 & Tier 2 \\
MH3 & Summer & {$[$ [SEM]-[AVS] } & 0.16 & Tier 2 \\
DH2 & Autumn & [SEM]-[AVS] & 18.6 & Tier 1 \\
& Autumn & ([SEM]-[AVS])/foc & 1189 & Tier 2 \\
\hline
\end{tabular}

[SEM]-[AVS] unit: $\mu \mathrm{mol} \mathrm{g}{ }^{-1}$ (dry weight); ([SEM]-[AVS])/foc unit: $\mu \mathrm{mol} \mathrm{g}{ }^{-1}$ OC (dry weight).

almost have no adverse effect on aquatic life in both seasons (Tables 4 and 5; Fig. 9).

However, not all sediments with $[$ SEM]-[AVS] $>0$ can cause increased toxicity because there are many other metal-binding phases in sediments, such as TOC (Burton et al., 2005; Di Toro et al., 2005; Brix et al., 2010; De Jonge et al., 2012a; De Jonge et al., 2012b). Hence, USEPA proposed a complementary evaluation method to evaluate the adverse biological effects of SEM taking into account the TOC concentrations in sediments, which is also a three-tier system: Tier 1, adverse biological effects may be expected (([SEM]-[AVS])/foC $>3000$, unit: $\mu \mathrm{mol} \mathrm{g}^{-1}$ OC); Tier 2 , adverse effects are uncertain (([SEM]-[AVS] $) / f_{\mathrm{OC}}=130$ to 3000$)$; Tier 3, adverse effects are not expected (([SEM]-[AVS])/foc $<130)$ (Table 4) (USEPA, 2005). According to this criterion, only the surface sediment at site DH2 fell in Tier 2 in autumn, which means its adverse biological effects are uncertain, while it had probable adverse effect on aquatic life by the AVS-SEM criterion; all the sediments of other sites might have no adverse effect in both seasons (Tables 4 and 5).

This research showed that biotoxic level of heavy metals might change from season to season. There are many factors affecting the concentrations and biotoxicity of heavy metals in sediments. Heavy metals may enter sediments from marinas and recreational vessel operation and maintenance (Guillen et al., 1993; Fairey et al. 2004; Hinkey et al., 2005). Wastewater from factories can also cause great heavy metal pollution. Studies showed that dredging process could increase the concentrations of sediment-bound metals in overlying water or even in undisturbed watercourses (De Jonge et al., 2012a). Metals that are combined with AVS may also be released from sediments through flood, storms, oxidation, etc., and may have adverse environmental impacts (van Den Berg et al., 1999; Prica et al., 2008). Therefore the combined actions of all the factors mentioned above can lead to AVS breakdown in surface sediments, thus causing heavy metals to release into the pore water and overlying water.

\subsection{The limitations of AVS-SEM evaluation method}

AVS-SEM method has been proved to be an efficient ecological risk assessment method; however, it still has some limitations. AVS concentration may change when environmental conditions $(\mathrm{pH}$, Eh, oxygen content, etc.) change, and then sediments without biological toxicity may produce biological toxicity. It seems that some of the sulfides measured as AVS were oxidized during the elutriation which could release metals into the water column. Therefore applying this theory to metal remobilization studies would be proper only in the case that sulfides are not oxidized during elutriation (Di Toro et al., 1990; Durán et al., 2012). During the past years, much evidence has shown that benthic invertebrates can accumulate metals, even when $[\mathrm{SEM}]-[\mathrm{AVS}]<0$, since benthic invertebrates ingest sediment particles as their main food source disregarding AVS (Lee et al., 2000a; Lee et al., 2000b; De Jonge et al., 2009; De Jonge et al., 2010).

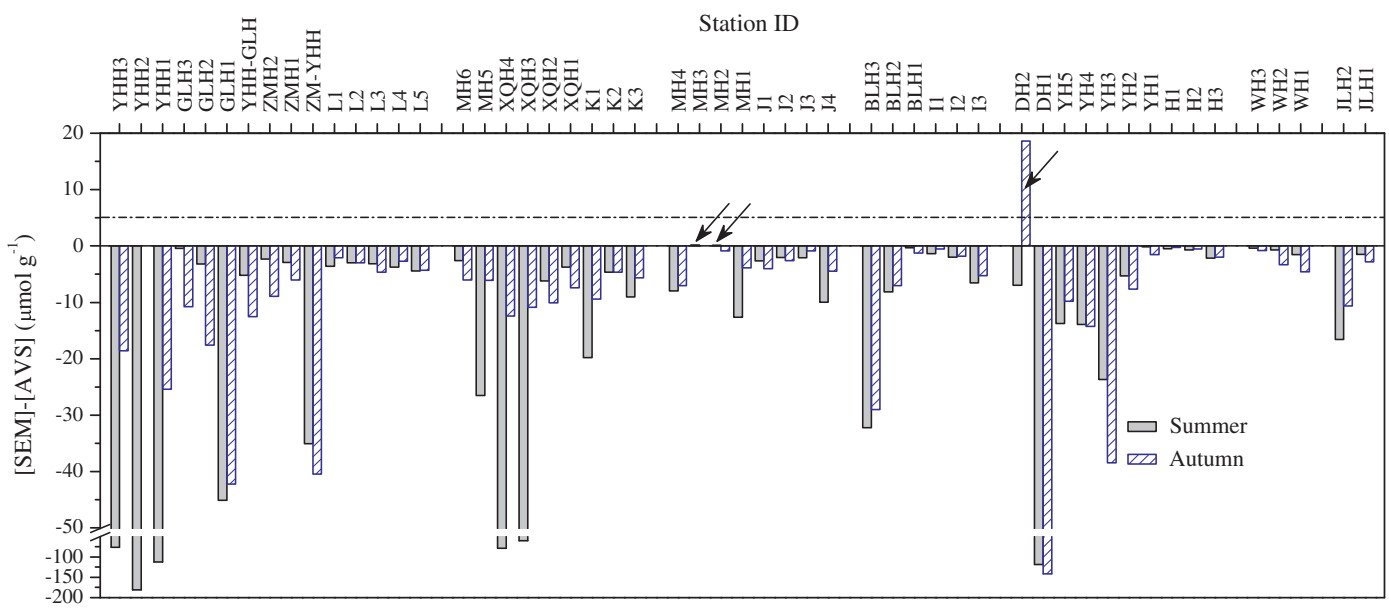

Fig. 9. Spatial distribution of [SEM]-[AVS] in surface sediments of the SW coastal Laizhou Bay. The arrows indicate the positive values. 
SEMs can be combined with AVS to reduce their toxicity; however, AVS of excessively high content is also harmful to aquatic organism. AVS is usually abundant in the organic-rich and reductive environment, because AVS is mainly formed by sulfate reduction in the process of the metabolism of SRB which are anaerobic bacteria (Myhr et al., 2002; Wang et al., 2004). The serious anoxic environment may lead to the death of benthic organisms and fish. During the sample collection process of this research, dead fish or shell-fish were found at some sampling stations where very low levels of Eh were detected, e.g. DH1, YH2 and YHH1, although there was no heavy metal pollution according to AVS-SEM theory at these stations. Sulfide ions released from AVS can combine with hydrogen ions to form $\mathrm{H}_{2} \mathrm{~S}$ which has a strong neurotoxicity, and can produce toxic effects on aquatic life and even on humans; $\mathrm{H}_{2} \mathrm{~S}$ can also corrode ships, industrial equipment and pipelines (Jack et al., 1992; Kim and Kim, 2001).

Therefore using only one single approach for quality assessment of sediments may not be sufficient; a comparison of the results based on different criteria for sediment quality assessment will be more convincing. We will carry out this work later.

\section{Conclusions}

Because of the influence of frequent anthropogenic activities and complex natural environment, both AVS and SEM concentrations in riverine sediments were higher and had greater spatial differences among sampling sites and between different seasons than those in marine sediments. Significant positive correlations were observed between [AVS] and [SEM] in both seasons, which implied that they had similar formative and existing conditions and that AVS was an important carrier for SEM. There were also significant positive correlations between all the five simultaneously extracted metals in pairs, which indicated that these metals were associated with each other and might have common anthropogenic and natural sources in the sediments.

In accordance with the USEPA criteria, except for a few riverine samples ( $\mathrm{MH} 2, \mathrm{MH} 3$ and $\mathrm{DH} 2$ ), heavy metals ( $\mathrm{Cd}, \mathrm{Ni}, \mathrm{Cu}, \mathrm{Pb}$ and $\mathrm{Zn}$ ) in surface sediments of coastal Laizhou Bay had no adverse biological effects in both summer and autumn. Anthropogenic influences might be responsible for the relatively higher SEM concentrations in riverine sediments. $\mathrm{Zn}$ was the major component in the total amount of SEM, whereas the contribution of much more toxic Cd to SEM was no more than $0.7 \%$. The average concentrations of SEM were in the following order: $\mathrm{Cd}$ $\ll \mathrm{Pb}<\mathrm{Ni}<\mathrm{Cu}<\mathrm{Zn}$.

This study showed that biotoxic level of heavy metals might change with time, and sediments without biological toxicity in one season might produce biological toxicity in another. Biotoxic level of heavy metals could be influenced by many factors such as redox potential, dissolved oxygen, flood, and anthropogenic influences. The present research is a very beginning for a systematic assessment of sediment quality in Laizhou Bay. In the near future we hope to use more assessment methods to obtain comprehensive information on the baseline, anthropogenic discharge and bioavailability of heavy metals in this area.

\section{Acknowledgements}

This study was co-supported by the National Natural Science Foundation of China (41376083), the Department of Science and Technology of Shandong Province (2012GHY11535) and the CAS/ SAFEA International Partnership Program for Creative Research Teams (Representative Environmental Processes and Resources Effects in Coastal Zones).

\section{References}

Allen, H.E., Fu, G., Deng, B., 1993. Analysis of acid-volatile sulfide (AVS) and simultaneously extracted metals (SEM) for the estimation of potential toxicity in aquatic sediments. Environmental Toxicology and Chemistry 12 (8), 14411453.

Almeida, C.M., Mucha, A.P., Vasconcelos, M.T., 2005. The role of a salt marsh plant on trace metal bioavailability in sediments, estimation by different chemical approaches. Environmental Science and Pollution Research 12 (5), 271-277.

Ankley, G.T., 1996. Evaluation of metal/acid-volatile sulfide relationships in the prediction of metal bioaccumulation by benthic macroinvertebrates. Environmental Toxicology and Chemistry 15 (12), 2138-2146.

Ankley, G.T., Di Toro, D.M., Hansen, D.J., 1996. Technical basis and proposal for deriving sediment quality criteria for metals. Environmental Toxicology and Chemistry 15 (2), 2056-2066.

Brix, K.V., Keithly, J., Santore, R.C., DeForest, D.K., Tobiason, S., 2010. Ecological risk assessment of zinc from stormwater runoff to an aquatic ecosystem. Science of the Total Environment 408 (8), 1824-1832.

Brouwer, H., Murphy, T.P., 1994. Diffusion method for the determination of acidvolatile sulphides (AVS) in sediment. Environmental Toxicology and Chemistry $13(8), 1273-1275$.

Burton Jr, G.A., Nguyen, L.T.H., Janssen, C., Baudo, R., Mcwilliam, R., Bossuyt, B., Beltrami, M., Green, A., 2005. Field validation of sediment zinc toxicity, Environmental Toxicology and Chemistry 24 (3), 541-553.

Castro, H.F., Williams, N.H., Ogram, A., 2000. Phylogeny of sulfate-reducing bacteria. Fems Microbiology Ecology 31 (1), 1-9.

De Jonge, M., Blust, R., Bervoets, L., 2010. The relation between Acid Volatile Sulfides (AVS) and metal accumulation in aquatic invertebrates: Implications of feeding behavior and ecology. Environmental Pollution 158 (5), 1381-1391.

De Jonge, M., Dreesen, F., De Paepe, J., Blust, R., Bervoets, L., 2009. Do Acid Volatile Sulfides (AVS) influence the accumulation of sediment-bound metals to benthic invertebrates under natural field conditions? Environmental Science and Technology 43 (12), 4510-4516.

De Jonge, M., Teuchies, J., Meire, P., Blust, R., Bervoets, L., 2012a. The impact of increased oxygen conditions on metal-contaminated sediments. Part I: Effects on redox status, sediment geochemistry and metal bioavailability. Water Research 46 (7), 2205-2214.

De Jonge, M., Teuchies, J., Meire, P., Blust, R., Bervoets, L., 2012b. The impact of increased oxygen conditions on metal-contaminated sediments. Part II: Effects on metal accumulation and toxicity in aquatic invertebrates. Water Research 46 (10), 3387-3397.

Di Toro, D.M., Mahony, J.D., Hansen, D.J., Scott, K.J., Hicks, M.B., Mayr, S.M., Redmond, M.S., 1990. Toxicity of cadmium in sediments: the role of acid volatile sulfide. Environmental Toxicology and Chemistry 9 (12), 1487-1502.

Di Toro, D.M., McGrath, J.A., Hansen, D.J., Berry, W.J., Paquin, P.R., Mathew, R., Wu, K.U., Santore, R.C., 2005. Predicting sediment metal toxicity using a sediment biotic ligand model: methodology and initial application. Environmental Toxicology and Chemistry 24 (10), 2410-2427.

Durán, I., Sánchez-Marín, P., Beiras, R., 2012. Dependence of $\mathrm{Cu}, \mathrm{Pb}$ and $\mathrm{Zn}$ remobilization on physicochemical properties of marine sediments. Marine Environmental Research 77, 43-49.

Fairey, R., Sigala, M., Pap, R., 2004. Condition of sediments in selected marinas of San Francisco Bay. Report Prepared for the San Francisco Bay Conservation and Development Commission. Moss Landing Marine Laboratories, Monterey, CA.

Fang, T., Li, X., Zhang, G., 2005. Acid volatile sulfide and simultaneously extracted metals in the sediment cores of the Pearl River Estuary, South China. Ecotoxicology and Environmental Safety 61 (3), 420-431.

Gao, X.L., Chen, C.T.A., 2012. Heavy metal pollution status in surface sediments of the coastal Bohai Bay. Water Research 46 (6), 1901-1911.

Gao, X.L., Chen, C.T.A., Wang, G., Xue, Q.Z., Tang, C., Chen, S.Y., 2010. Environmental status of Daya Bay surface sediments inferred from a sequential extraction technique. Estuarine, Coastal and Shelf Science 86 (3), 369-378.

Gao, X.L., Chen, S.Y., Long, A.M., 2008. Chemical speciation of 12 metals in surface sediments from the northern South China Sea under natural grain size. Marine Pollution Bulletin 56 (4), 786-792.

Gao, X.L., Li, P.M., 2012. Concentration and fractionation of trace metals in surface sediments of intertidal Bohai Bay, China. Marine Pollution Bulletin 64 (8), 15291536.

Gao, X.L., Li, P.M., Chen, C.T.A., 2013. Assessment of sediment quality in two important areas of mariculture in the Bohai Sea and the northern Yellow Sea based on acid-volatile sulfide and simultaneously extracted metal results. Marine Pollution Bulletin 72 (1), 281-288.

Guillen, G., Ruckman, M., Smith, S., Broach, L., 1993. Marina Impacts in Clean Lake and Galveston Bay. Special Report D7-001A Prepared for the Texas Water Commission, Houston, TX.

Hinkey, L.M., Zaidi, B.R., Volson, B., Rodriguez, N., 2005. Identifying sources and distributions of sediment contaminants at two US Virgin Islands marinas. Marine Pollution Bulletin 50 (11), 1244-1250.

Hinkey, L.M., Zaidi, B.R., 2007. Differences in SEM-AVS and ERM-ERL predictions of sediment impacts from metals in two US Virgin Islands marinas. Marine Pollution Bulletin 54 (2), 180-185.

Huerta-Diaz, M.A., Tessier, A., Carignan, R., 1998. Geochemistry of trace metals associated with reduced sulphur in freshwater sediments. Applied Geochemistry 13 (2), 213-233. 
Hu, N.J., Shi, X.F., Liu, J.H., Huang, P., Yang, G., Liu, Y.G., 2011. Distributions and impacts of heavy metals in the surface sediments of the Laizhou Bay. Advances in Marine Science 29 (1), 63-72 (In Chinese with English abstract).

Ip, C.C.M., Li, X.D., Zhang, G., Wai, O.W.H., Li, Y.S., 2007. Trace metal distribution in sediments of the Pearl River Estuary and the surrounding coastal area, South China. Environmental Pollution 147 (2), 311-323.

Jack, R.F., Ringelberg, D.B., White, D.C., 1992. Differential corrosion rates of carbon steel by combinations of Bacillus sp., Hafnia alvi and Desulfovibrivo gigas established by phospholipids analysis of electrode biofilm. Corrosion Science 33 (12), 1843-1853.

Jacob, D.L., Otte, M.L., 2004. Long-term effects of submergence and wetland vegetation on metals in a 90-year old abandoned $\mathrm{Pb}, \mathrm{Zn}$ mine tailings pond. Environmental Pollution 130 (3), 337-345.

Jiang, W.S., Pohlmann, T., Sudermann, J., Feng, S.Z., 2000. A modeling study of SPM transport in the Bohai Sea. Journal of Marine Systems 24 (3-4), 175-200.

Kim, J.G., Kim, Y.W., 2001. Cathodic protection criteria ofthermally insulated pipeline buried in soil. Corrosion Science 43 (11), 2011-2021.

Lee, B.G., Griscom, S.B., Lee, J.S., Choi, H.J., Koh, C.H., Luoma, S.N., Fisher, N.S., 2000a. Influences of dietary uptake and reactive sulfides on metal bioavailability from aquatic sediments. Science 287 (5451), 282-284.

Lee, B.G., Lee, J.S., Luoma, S.N., Choi, H.J., Koh, C.H., 2000b. Influence of acid volatile sulfide and metal concentrations on metal bioavailability to marine invertebrates in contaminated sediments. Environmental Science \& Technology 34 (21), 4511-4516.

Leonard, E.N., Cotter, A.M., Ankley, G.T., 1996. Modified diffusion method for analysis of acid volatile sulphides and simultaneously extracted metals in freshwater sediment. Environmental Toxicology and Chemistry 15 (9), 14791481.

Liu, J.C., Yan, C.L., Kate, L.S., Zhang, R.F., Lu, H.L., 2010. The distribution of acidvolatile sulfide and simultaneously extracted metals in sediments from a mangrove forest and adjacent mudflat in Zhangjiang Estuary, China. Marine Pollution Bulletin 60 (8), 1209-1216.

Liu, J., Yan, C., Macnair, M.R., Hu, J., Li, Y., 2007. Vertical distribution of acid-volatile sulfide and simultaneously extracted metals in mangrove sediments from the Jiulong River Estuary, Fujian, China. Environmental Science and Pollution Research 14 (5), 345-349.

Liu, Y.H., Yang, X.L., Jin, Y., Tang, X.C., Bai, Y.Y., Sun, S., Tao, H.M., Gu, W.L., Wang, G.H., 2011. Distribution and inter-annual variation of nutrient in Laizhou Bay. Progress in Fishery Sciences 32 (4), 1-5 (In Chinese with English abstract).

Long, E.R., Field, L.J., Mac Donald, D.D., 1998. Predicting toxicity in marine sediments with numerical sediment quality guidelines. Environmental Toxicology and Chemistry 17 (4), 714-727.

Long, E.R., MacDonald, D.D., Smith, S.C., Calder, F.D., 1995. Incidence of adverse biological effects within ranges of chemical concentrations in marine and estuarine sediments. Environmental Management 19 (1), 81-97.

Machado, W., Santelli, R.E., Carvalho, M.F., Molisani, M.M., Barreto, R.C., Lacerda, L.D. 2008. Relation of reactive sulfides with organic carbon, iron, and manganese in anaerobic mangrove sediments: implications for sediment suitability to trap trace metals. Journal of Coastal Research 24 (4A), 25-32.

McGrath, J.A., Paquin, P.R., Di Toro, D.M., 2002. Use of the SEM and AVS Approach in Predicting Metal Toxicity in Sediments. Fact Sheet on Environmental Risk Assessment. Published by the International Council on Mining and Metals (ICMM). No. 10. London, UK.

Morita, R.Y., 1975. Psychrophilic bacteria. Bacteriological Reviews 39 (2), 144-167.

Morse, J.W., Millero, F.J., Cornwell, J.C., Rickard, D., 1987. The chemistry of hydrogen sulfide and iron sulfide systems in natural waters. Earth-Science Reviews 24 (1), $1-42$.

Myhr, S., Lillebø, B.L., Sunde, E., Beeder, J., Torsvik, T., 2002. Inhibition of microbial $\mathrm{H}_{2} \mathrm{~S}$ production in an oil reservoir model column by nitrate injection. Applied Microbiology and Biotechnology 58 (3), 400-408.
Prica, M., Dalmacija, B., Rončević, S., Krčmar, D., Bečelić, M., 2008. A comparison of sediment quality results with acid volatile sulfide (AVS) and simultaneously extracted metals (SEM) ratio in Vojvodina (Serbia) sediments. Science of the Total Environment 389 (2-3), 235-244.

Qian, S.Q., Shi, X.F., Zhu, A.M., Liu, Y.G., Bi, N.S., Fang, X.S., Yang, G., 2010 Distribution and transport of suspended sediments off the Yellow River (Huanghe) mouth and the nearby Bohai Sea. Estuarine, Coastal and Shelf Science 86 (3), 337-344.

Sahuquillo, A., Rigol, A., Rauret, G., 2003. Overview of the use of leaching/extraction tests for risk assessment of trace metals in contaminated soils and sediments. Trends in Analytical Chemistry 22 (3), 152-159.

Simpson, S.L., Apte, S.C., Batley, G.E., 1998. Effect of short-term resuspension events of tracemetal speciation in polluted anoxic sediments. Environmental Science and Technology 32 (5), 620-625.

Simpson, S.L., Ward, D., Strom, D., Jolley, D.F., 2012. Oxidation of acid-volatile sulfide in surface sediments increases the release and toxicity of copper to the benthic amphipod Melita plumulosa. Chemosphere 88 (8), 953-961.

Soares, H.M.V.M., Boaventura, R.A.R., Machado, A.A.S.C., da Silva, J.C.G.E., 1999. Sediments as monitors of heavy metal contamination in the Ave river basin (Portugal): multivariate analysis of data. Environmental Pollution 105 (3), 311-323.

SOA (State Oceanic Administration of China), 2009. Marine Environment Quality Bulletin of China, 2008. <http://www.coi.gov.cn/gongbao/nrhuanjing/nr2008/ 201107/t20110729_18793.html>. (In Chinese).

SOA (State Oceanic Administration of China), 2012. Marine Environment Quality Bulletin of China, 2011. <http://www.coi.gov.cn/gongbao/nrhuanjing/nr2011 201207/t20120710_23199.html>. (In Chinese).

USEPA (United States Environmental Protection Agency), 2004. The Incidence and Severity of Sediment Contamination in Surface Waters of the United States (National Sediment Quality Survey. EPA-823-R-04-007, second ed., Washington, DC: United States Environmental Protection Agency, Office of Science and Technology).

USEPA (United States Environmental Protection Agency), 2005. Procedures for the Derivation of Equilibrium Partitioning Sediment Benchmarks (ESBs) for the Protection of Benthic Organisms: Metal Mixtures (Cadmium, Copper, Lead, Nickel, Silver, and Zinc) (EPA-600-R-02-011, Washington, DC: United States Environmental Protection Agency, Office of Research and Development).

van Den Berg, G.A., Loch, J.P.G., van Der Heijdt, L.M., Zwolsman, J.J.G., 1999 Mobilisation of heavy metals in contaminated sediments in the river Meuse, The Netherlands. Water Air and Soil Pollution 116 (3-4), 567-586.

van Griethuysen, C. Gillissen, F., Koelmans, A.A, 2002. Measuring acid volatile sulphide in floodplain lake sediments: effect of reaction time, sample size and aeration. Chemosphere 47 (4), 395-400.

van Griethuysen, C., de Lange, H.J., van den Heuij, M., de Bles, S.C., Gillissen, F. Koelmans, A.A., 2006. Temporal dynamics of AVS and SEM in sediment of shallow freshwater floodplain lakes. Applied Geochemistry 21 (4), 632-642.

Wang, W., Wang, J., Li, X., Xu, H., Wu, J., 2004. Influence of biofilms growth on corrosion potential of metals immersed in seawater. Materials and CorrosionWerkstoffe Und Korrosion 55 (1), 30-35.

Wijsman, J.W.M., Middelburg, J.J., Herman, P.M.J., Bottcher, M.E., Heip, C.H.R., 2001 Sulfur and iron speciation in surface sediments along the northwestern margin of the Black Sea. Marine Chemistry 74 (4), 261-278.

Wilson, D.J., Chang, E., 2000. Bioturbation and the oxidation of sulfide in sediments. Journal of the Tennessee Academy of Science 75 (3-4), 76-85.

Xia, B., Zhang, X.L., Cui, Y., Chen, B.J., Chen, J.F., Guo, F., Zhang, Y., Huang, C.L., 2009 Evaluation of the physicochemical environment and nutrition status in Laizhou Bay and adjacent waters in summer. Progress in Fishery Sciences 30 (3), 103 111 (In Chinese with English abstract).

Yang, Y.Q., Chen, F.R., Zhang, L., Liu, J.S., Wu, S.J., Kang, M.L., 2012. Comprehensive assessment of heavy metal contamination in sediment of the Pearl River Estuary and adjacent shelf. Marine Pollution Bulletin 64 (9), 1947-1955. 